\title{
Preservation of roasted and ground coffee during storage. Part 2: Bulk density and intergranular porosity
}

\author{
Paulo C. Corrêa ${ }^{1}$, Gabriel H. H. de Oliveira ${ }^{2}$, Wander L. Vasconcelos ${ }^{3}$, \\ Guillermo A. Vargas-Elías ${ }^{4}$, Fábio L. Santos ${ }^{5}$ \& Eduardo H. M. Nunes ${ }^{3}$ \\ ${ }^{1}$ Universidade Federal de Viçosa/Departamento de Engenharia Agrícola. Viçosa, MG. E-mail: copace@ufv.br \\ ${ }^{2}$ Instituto Federal do Sudeste de Minas Gerais. Manhuaçu, MG. E-mail: gabriel.oliveira@ifsudestemg.edu.br (Corresponding author) \\ ${ }^{3}$ Universidade Federal de Minas Gerais/Departamento de Engenharia Metalúrgica e de Materiais. Belo Horizonte, MG. E-mail: wlv@demet.ufmg.br; \\ eduardohmn@gmail.com \\ ${ }^{4}$ Universidad de Costa Rica/Centro de Investigaciones en Granos y Semillas/Facultad Ciencias Agroalimentarias. San José, Costa Rica. E-mail: gvargase@gmail.com \\ ${ }^{5}$ Universidade Federal de Lavras/Departamento de Engenharia. Lavras, MG. E-mail: fabio.santos@deg.ufla.br
}

Key words:

Coffea arabica

Coffea canephora

physical properties

\begin{abstract}
A B S T R A C T
The determination of physical properties is an important factor in the design of machinery and the scaling of post-harvest operations. The present study evaluates the influence of the level of roasting and the size of grinding on the physical properties of coffee during storage. The following physical properties were evaluated: true and bulk density, and intergranular porosity. Raw coffee beans (Coffea canephora and Coffea arabica), hulled and dried, were roasted to two different levels: medium light (SCAA\#65) and moderately dark (SCAA\#45). The beans were then grinded into three different sizes: fine $(0.59 \mathrm{~mm})$, medium $(0.84 \mathrm{~mm})$ and coarse $(1.19 \mathrm{~mm})$. An additional coffee lot was kept whole. Following grinding, samples were stored at two different temperatures $\left(10\right.$ and $\left.30^{\circ} \mathrm{C}\right)$ and analyzed after five different storage durations $(0,30,60,120$ and 180 days). The medium light roast had higher values for each of the measured physical properties. Finely ground samples had higher true and bulk densities, and porosities. It is concluded that the size of grinding, level of roasting and duration of storage significantly affect the physical properties of coffee.
\end{abstract}

\section{Palavras-chave: \\ Coffea arabica \\ Coffea canephora \\ propriedades físicas}

\section{Conservação de café torrado e moído durante o armazenamento. Parte 2: Massa específica e porosidade}

\section{R E S U M O}

A determinação das propriedades físicas é fator importante na formulação de projetos de maquinários e dimensionamento de operações pós-colheita. De forma a permitir o dimensionamento correto e o uso desses maquinários, objetivou-se avaliar e determinar, durante o armazenamento, as propriedades físicas: massa específica unitária e aparente e porosidade intergranular, além de avaliar a influência dos níveis de torrefação e moagem sobre essas propriedades. Grãos de café cru (Coffea canephora e Coffea arabica) foram utilizados, descascados e secados e só então torrados em dois níveis: média clara (SCAA\#65) e moderadamente escura (SCAA\#45). Os grãos foram moídos em três granulometrias: fina $(0,59$ $\mathrm{mm})$, média $(0,84 \mathrm{~mm})$ e grossa $(1,19 \mathrm{~mm})$, além do lote de café inteiro. Realizada a moagem as amostras foram armazenadas em duas temperaturas $\left(10\right.$ e $\left.30^{\circ} \mathrm{C}\right)$ e analisadas em cinco tempos distintos de armazenamento $(0,30,60,120$ e 180 dias $)$. A torra média clara permitiu maiores valores das propriedades físicas; já as amostras de granulometria fina apresentaram aumento das massas específica unitária e aparente e porosidade. Conclui-se que a granulometria, o nível de torrefação e o tempo de armazenamento, afetaram as propriedades físicas do café.

Ref. 090-2015 - Received 30 Jun, 2015 • Accepted 26 Apr, 2016 • Published 3 Jun, 2016 


\section{INTRODUCTION}

The preservation of whole and ground roasted coffee is necessary for its commercialization. Different factors can influence the preservation of coffee and, consequently, its final quality, such as roasting, grinding and storage.

Roast level has been reported to determine the final quality of the beverage (Melo, 2004; Baggenstoss et al., 2008), and significant changes to coffee's physical properties have been observed to occur during roasting (Mwithiga \& Jindal, 2003). Grinding results in powdery products that can have different particle sizes according to the market's needs (Schmidt et al., 2008) and affect the physical properties of coffee (Geldart et al., 2009; Langroudi et al., 2010).

Storage of roasted and ground coffee is not recommended because grinding promotes cell breakage and, therefore, enables the loss of molecular components, negatively affecting quality. However, studying the physical properties of roasted and ground coffee is important due to potential market conditions. Previously processed products may need to be stored due to a lack of transportation, prices that make immediate commercialization impossible and the need to formulate coffee blends. In addition, bulk storage can be a great advantage, because it enables the mechanization of coffee processing, which substantially decreases the amount of labor required compared to traditional storage methods (Oliveira et al., 2014). Storage time was also observed to influence the physical properties of other products such as wheat flour, tea, whey (Teunou \& Fitzpatrick, 2000; Iqbal \& Fitzpatrick, 2006), dairy powders (Fitzpatrick et al., 2007) and poultry feed (Nóbrega \& Nascimento, 2005; Lopes Neto et al., 2009).

The aim of the present study was to evaluate physical properties (true density, bulk density and intergranular porosity) of coffee roasted to different levels, ground to different sizes and stored at different temperatures.

\section{Material ANd Methods}

The present study was performed at the Laboratory of Physical Properties and Quality of Agricultural Products of the National Center of Storage Training (CENTREINAR) located at the Federal University of Viçosa-MG, Brazil, and at the Laboratory of Ceramic Materials of the Department of Metallurgical and Materials of the Federal University of Minas Gerais, in Belo Horizonte, MG.

Raw coffee beans (Coffea canephora and Coffea arabica), hulled and dried, were acquired from the regional markets of Zona da Mata, Minas Gerais. The beans were sorted to eliminate deteriorated, damaged and bored beans and to obtain a homogeneous lot with minimal defects. The initial moisture content of the beans was determined through gravimetry using a forced-air circulation oven at $105 \pm 1{ }^{\circ} \mathrm{C}$ for $24 \mathrm{~h}$ in triplicate. The average initial moisture content was $12.61 \%$ (dry basis).

Following sorting, coffee beans from both species were roasted using a direct-flame LPG gas roaster with a rotating cylinder at $45 \mathrm{rpm}$ with a $350 \mathrm{-g}$ raw coffee roasting capacity. The different roast levels were identified through monitoring and comparison of sample colors with the Agtron color reference standards, with the assistance of a trained professional. Two roast levels were obtained: medium light (ML) and moderately dark (MD), corresponding to the Agtron standards SCAA\#65 and SCAA\#45, respectively (Figure 1 ).

To guarantee the uniformity of the roast, a portable infrared thermometer (Mult-Time) with a temperature range of -50 to $500{ }^{\circ} \mathrm{C}, 1 \mathrm{~s}$ response time and $0.1^{\circ} \mathrm{C}$ resolution was used. ML and $\mathrm{MD}$ roasted beans lost an average of 15.85 and $18.74 \mathrm{~g}$ when the roaster reached $285^{\circ} \mathrm{C}$, respectively (Vargas-Elías, 2011). When each roast level was reached, the beans were removed from the roaster and immediately cooled at ambient temperature.

Following roasting, the beans were ground with a mill (Mahlkönig) into three different grind sizes according to the ABIC (2013) (Table 1): fine $(0.59 \mathrm{~mm})$, medium $(0.84 \mathrm{~mm})$ and coarse $(1.19 \mathrm{~mm})$. An additional lot was kept whole.

The processed samples were then placed in polypropylene bags and stored in B.O.D. chambers at two different temperatures $\left(10\right.$ and $\left.30^{\circ} \mathrm{C}\right)$ for six months. Physical properties of the stored samples were analyzed at five different times during storage $(0,30,60,120$ and 180 days $)$ as described below.

A.
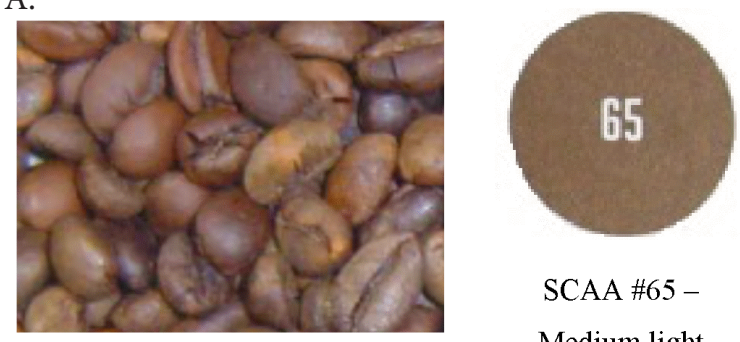

SCAA \#65 -

Medium light

B.
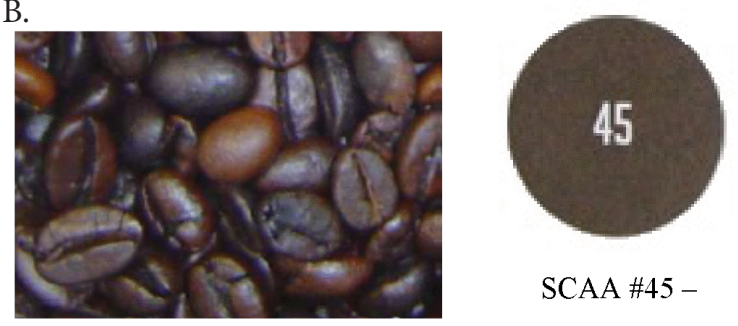

SCAA \#45 -

Moderately dark

Figure 1. Roasting degrees employed: medium light (A) and moderately dark (B)

Table 1. Classification based on the percentage retention in sieve numbers 12, 16, 20, 30 and at the sieve bottom pan, with agitation for $10 \mathrm{~min}$ and the rheostat set at position 5

\begin{tabular}{|c|c|c|c|c|c|}
\hline \multirow{2}{*}{ Grinding } & \multicolumn{3}{|c|}{ \% Retention } & \multicolumn{2}{|c|}{ Tolerance \% passing through sieve 30} \\
\hline & Sieve 12 and 16 & Sieve 20 and 30 & Sieve bottom pan & Minimum & Maximum \\
\hline Coarse & 33 & 55 & 12 & 9 & 15 \\
\hline Medium & 7 & 73 & 20 & 16 & 24 \\
\hline Fine & 0 & 90 & 30 & 25 & 40 \\
\hline
\end{tabular}

Source: ABIC (2013) 
True density $\left(\rho_{u}\right)$ was determined using a helium pycnometer, according to Eqs. 1 and 2, with five replicates. The helium pycnometer used was a Multipycnometer MVP-4DC (Quantachrome Corporation, USA), which operates according to the gas displacement principle.

$$
\begin{gathered}
\mathrm{P}_{1}\left(\mathrm{~V}_{\mathrm{c}}-\mathrm{V}_{\mathrm{s}}\right)=\mathrm{P}_{2}\left(\mathrm{~V}_{\mathrm{c}}-\mathrm{V}_{\mathrm{s}}+\mathrm{V}_{\mathrm{e}}\right) \\
\rho_{\mathrm{u}}=\frac{\mathrm{m}_{\mathrm{g}}}{\mathrm{V}_{\mathrm{s}}}
\end{gathered}
$$

where:

$$
\begin{array}{ll}
\mathrm{P}_{1} & \text { - initial pressure, } \mathrm{Pa} ; \\
\mathrm{P}_{2} & \text { - final pressure, } \mathrm{Pa} ; \\
\mathrm{V}_{\mathrm{c}} & \text { - volume of the sample chamber, } \mathrm{m}^{3} ; \\
\mathrm{V}_{\mathrm{s}} & \text { - sample volume }(\text { coffee }), \mathrm{m}^{3} ; \\
\mathrm{V}_{\mathrm{e}} & \text { - volume of the expansion chamber, } \mathrm{m}^{3} ; \\
\rho_{\mathrm{u}} & \text { - true density, } \mathrm{kg} \mathrm{m}^{-3} ; \text { and, } \\
\mathrm{m}_{\mathrm{g}} & \text { - roasted coffee weight, } \mathrm{kg} .
\end{array}
$$

Bulk density $\left(\rho_{\text {ap }}\right)$ was determined using a Burrows hectoliter weight scale, with 1-L capacity, on a steel plate, with five replicates. Intergranular porosity $(\varepsilon)$ was determined indirectly according to Eq. 3 (Mohsenin, 1986), traditionally used for agricultural products.

$$
\varepsilon=\left(1-\frac{\rho_{\text {ap }}}{\rho_{\mathrm{u}}}\right) \times 100
$$

where:

$\varepsilon \quad$ - intergranular porosity, \%; and,

$\rho_{\text {ap }} \quad$ - bulk density, $\mathrm{kg} \mathrm{m}^{-3}$.

The experimental design was completely randomized, with the number of replicates varying depending on the physical property measured. Two experiments were performed: one using Coffea arabica L. (cv. 'Catuai vermelho') and another one using Coffea canephora Pierre (cv. 'Emcapa 8111'). ANOVA, followed by Tukey's test, was performed for both experiments, with significance at $\mathrm{p}<0.05$. All statistical analyses were performed using SAEG ${ }^{\otimes}$ software. For the comparison of different storage times, a regression analysis using average values was performed. The best-fit models were selected based on the highest coefficient of determination $\left(R^{2}\right)$ and the significance of the parameters.

\section{Results AND Discussion}

Roast level, storage temperature, storage time and grind size affected the true density $\left(\rho_{\mathrm{u}}\right)$ of roasted coffee, regardless of the coffee species tested. Thus, only the results of Arabica coffee will be presented (Figure 2).

Higher grind sizes, which result in smaller particle sizes, resulted in higher $\rho_{u}$ (Figure 2). This result is based on the fact that, for a given constant volume, finer ground coffees were more tightly agglomerated, resulting in higher weights per volume, whereas larger particles undergo less agglomeration,

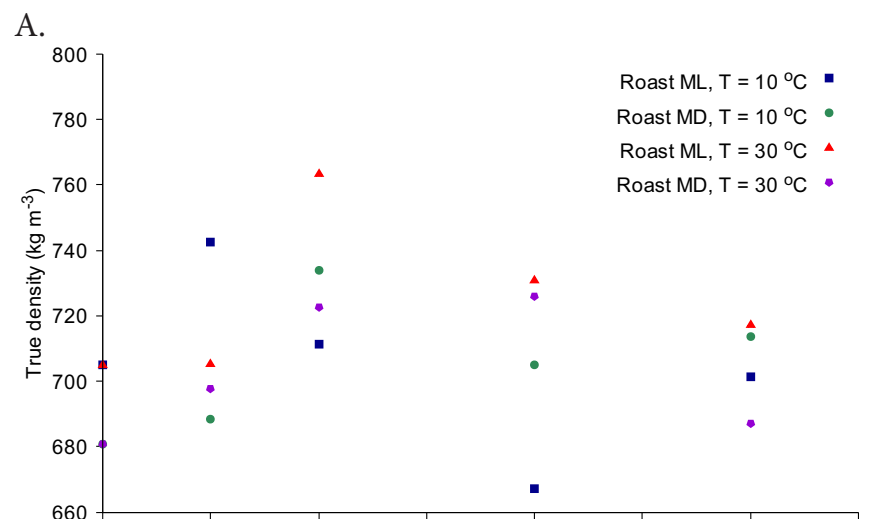

B.

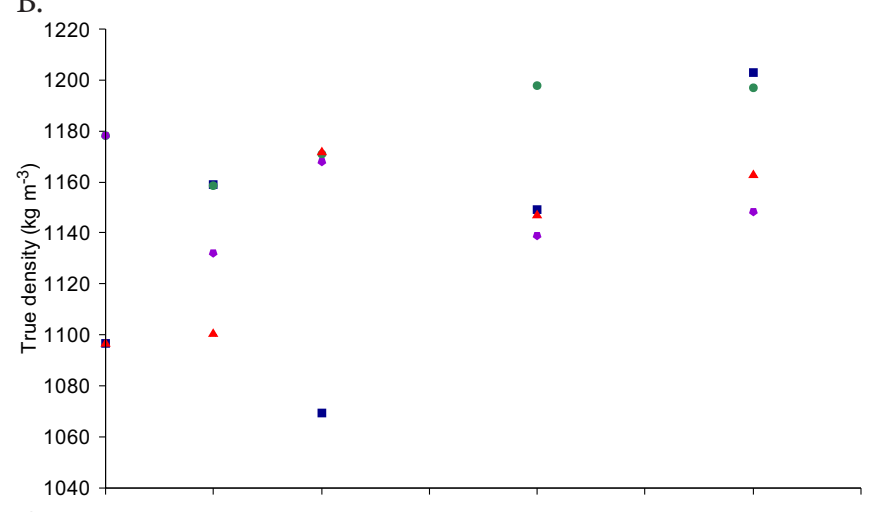

C.
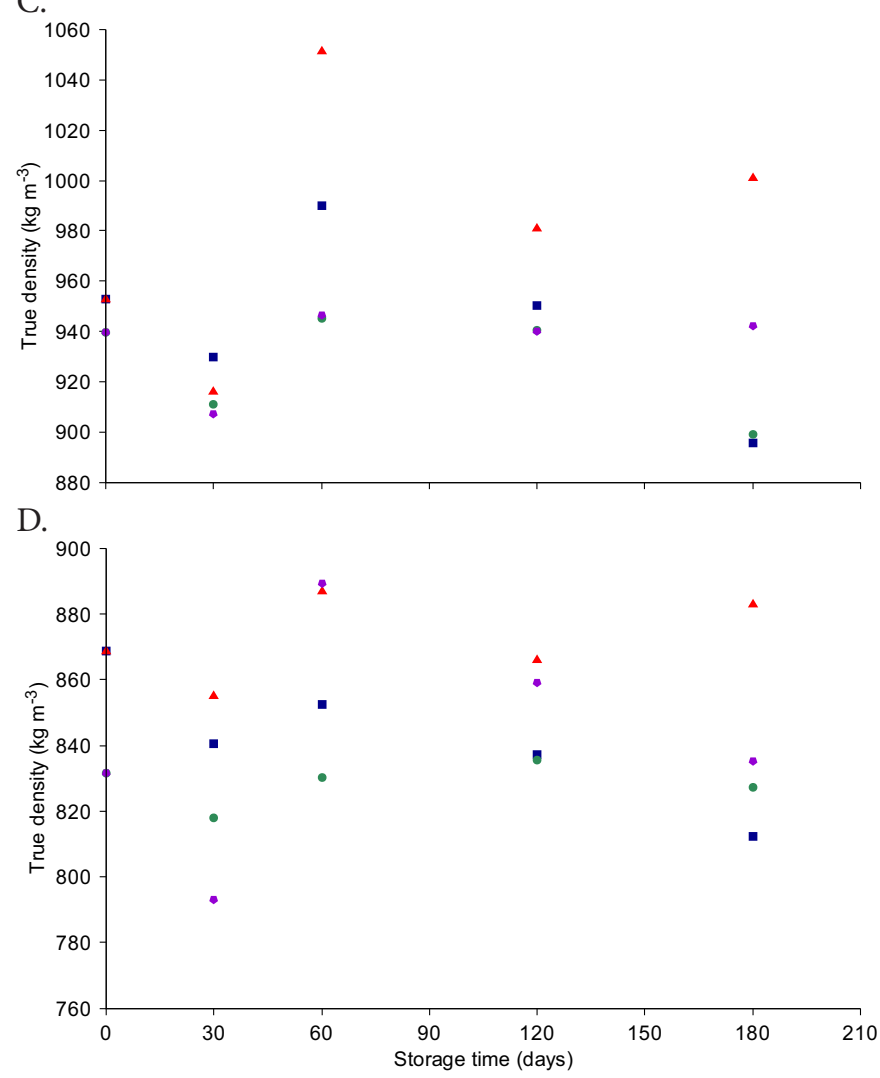

Values are averages

Figure 2. True density of roasted Arabica coffee during storage at 10 and $30{ }^{\circ} \mathrm{C}$. Coffee beans were whole (A) or ground, with fine (B), medium (C) or coarse (D) grind sizes

resulting in lower weights and, consequently, lower $\rho_{\mathrm{u}}$ values (Singh et al., 1997).

Medium light roasted coffee exhibited higher $\rho_{\mathrm{u}}$, regardless the coffee species (Figure 2). This result is explained by the variations in volume and weight during roasting: lighter roast 
levels result in smaller volume increases and less weight loss, resulting in higher $\rho_{\mathrm{u}}$. Singh et al. (1997) studied Mexican and Colombian coffee and also concluded that higher roast levels result in decreased $\rho_{\mathrm{u}}$. Vargas-Elías (2011) reported a $\rho_{\mathrm{u}}$ decrease in coffee with higher roast levels due to greater weight loss.

The differences in $\rho_{u}$ at different roast levels may also be explained by changes at the cellular level. Licciardi et al. (2005) reported that the triglycerides (oils) of coffee beans are mainly unaffected by roasting, suffering only slight hydrolysis and decomposition, with the release of fatty acids and the formation of volatile products. However, in darker roasted coffee, many cells break and oils may migrate to the surface (França et al., 2001), resulting in greater weight loss and decreases in $\rho_{u}$. This effect has also been observed in milk powder (Fitzpatrick et al., 2004).

Storage at $10^{\circ} \mathrm{C}$ resulted in the maintenance of the initial $\rho_{u}$ values (post-roasting). This result was mainly due to maintenance of volume. This finding, together with the small changes in weight due to moisture absorption, resulted in small variations of $\rho_{\mathrm{u}}$ during storage. Samples stored at $30^{\circ} \mathrm{C}$ exhibited greater variations in $\rho_{u}$. This result was due to more agglomeration at the higher storage temperature, which affected $\rho_{\mathrm{u}}$.

During storage, $\rho_{u}$ exhibited a general tendency to decrease compared to its initial values (Figure 2), because true density depends on moisture content and decreases with increased moisture content (Resende et al., 2008; Oliveira et al., 2015). This behavior was observed in the present study; a more pronounced decrease in $\rho_{\mathrm{u}}$ was observed starting at 60 days of storage and was accompanied by increased moisture content, as previously discussed.

Roast level, storage temperature, storage time and grind size also had effects on the bulk density of roasted coffee, regardless of the species studied. Thus, only the results of Robusta coffees during storage for six months will be presented (Figure 3).

Bulk density was influenced by the interaction between roast level and grind size, varying between 300 and $410 \mathrm{~kg} \mathrm{~m}^{-3}$. These values are within the range of 300 to $450 \mathrm{~kg} \mathrm{~m}^{-3}$ reported by Illy \& Viani (1995) for roasted coffee.

Whole coffee beans showed higher $\rho_{\text {ap }}$ compared with ground coffee. This result is directly related to the content of volatile components, which are related to the total weight of the product. Whole beans release $\mathrm{CO}_{2}$ slowly, with complete release occurring after approximately 30 days, whereas $70 \%$ of the $\mathrm{CO}_{2}$ content is released immediately following grinding. This results in higher weights for whole beans (Illy \& Viani, 1995).

For ground coffee, $\rho_{\text {ap }}$ decreased with increased particle size. Yan \& Barbosa-Canovas (1997) studied the compression characteristics of food powders and also reported this relationship between grind size and $\rho_{\text {ap }}$. The authors explained that higher particle sizes result in the product occupying less volume, i.e., there are more pores and, therefore, lower weights per volume, resulting in lower $\rho_{\text {ap }}$.

As observed for $\rho_{u}$, medium light roasted coffee exhibited higher $\rho_{\text {ap }}$ due to its lower weight loss and lower roasting time. This effect was previously observed in several studies on coffee (Illy \& Viani, 1995; Singh et al., 1997; Mwithiga \& Jindal, 2003; Mendonça et al., 2009; Vargas-Elías, 2011). Moderately dark
A.

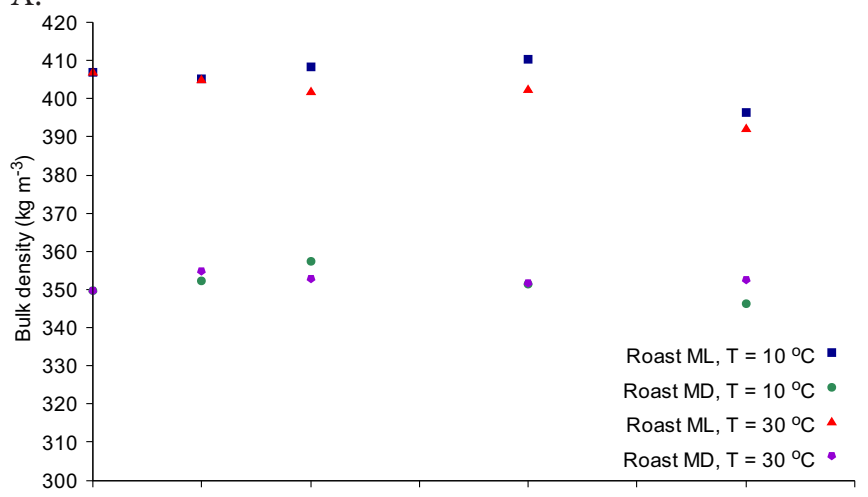

B.

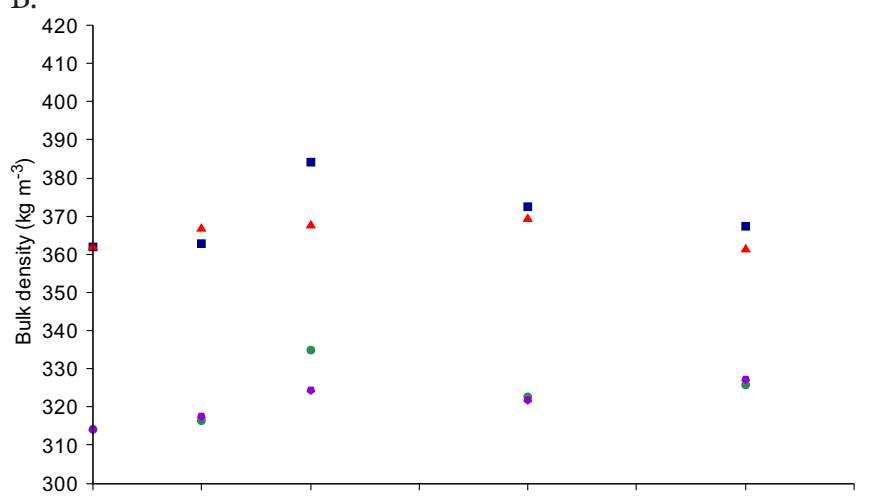

C.

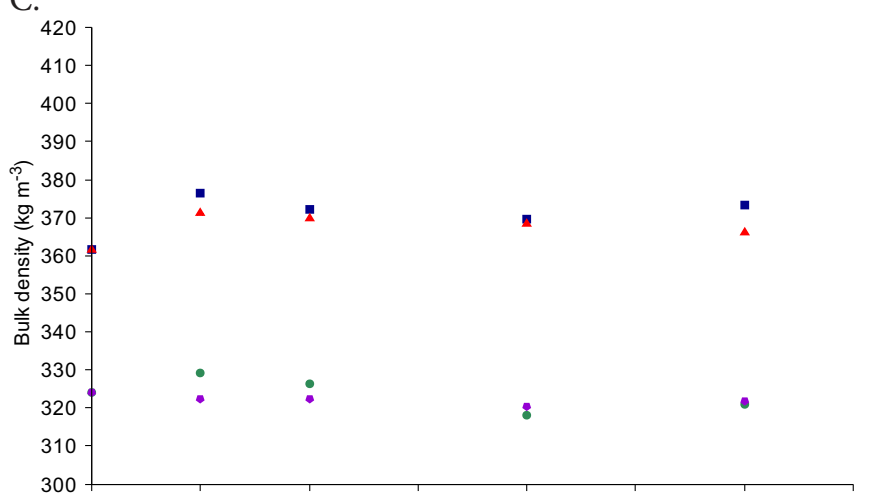

D.

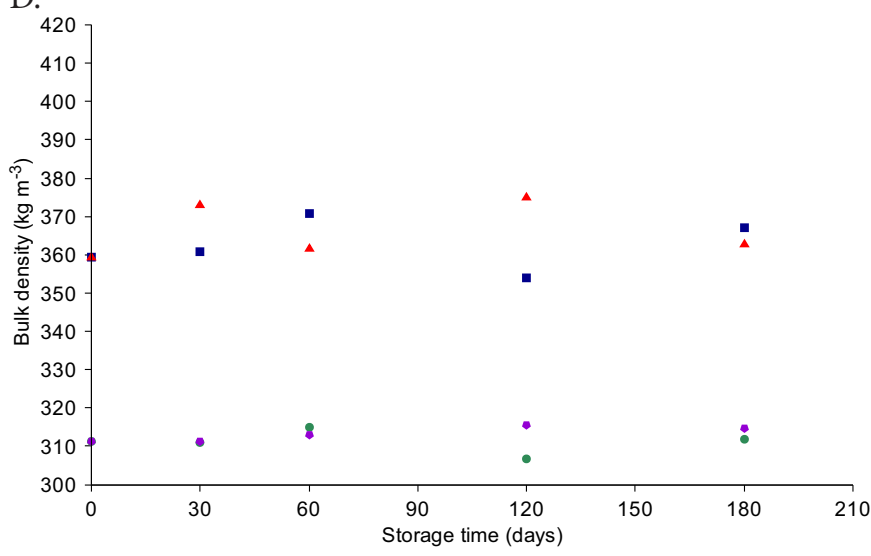

Values are averages

Figure 3. Bulk density of roasted Robusta coffee during storage at 10 and $30{ }^{\circ} \mathrm{C}$. Coffee beans were whole (A) or ground, with fine $(B)$, medium $(C)$ or coarse $(D)$ grind size

roasting results in greater weight loss and increased coffee volume and, therefore, lower $\rho_{\mathrm{ap}}$. The change in volume is related to the increase in internal cell pressure that occurs during heat transfer and in pyrolysis reactions, which are more intense during longer roasts (Borges et al., 2004). 
Storage at $30^{\circ} \mathrm{C}$ resulted in a more pronounced decrease in $\rho_{\text {ap }}$ in comparison to storage at $10^{\circ} \mathrm{C}$ (Figure 3). Adequate storage temperatures enable the preservation and/or decrease the loss of cellular components of agricultural products, resulting in better preservation during the shelf life of a product, which is consistent with the present results. This effect was observed more clearly in medium light roasted coffee (ML), indicating that the roast level may have more significant effects on the physical properties of coffee than on the storage temperature.

An effect between coffee roast level and grind size was observed with respect to intergranular porosity. The results of samples stored at $30^{\circ} \mathrm{C}$ are not presented because no significant differences were observed between the two storage temperatures tested, regardless of the species of coffee evaluated. The variation in intergranular porosity during storage at $10^{\circ} \mathrm{C}$ is presented in Figure 4 .

Intergranular porosity varied with grind level, with higher intergranular porosity observed in finely ground coffee and decreasing with increasing particle size. The lowest intergranular porosity was observed in whole beans (Figure 4), due to agglomeration.

Schubert (1987) reported that intergranular porosity increases with decreased particle size, because the adhesion between particles permits a loose structure. Pegg \& Shahidi (2007) reported that products with lower grind sizes tend to agglomerate, forming aggregates larger than the bean itself and resulting in higher intergranular porosity, which is in agreement with the present study.

A.
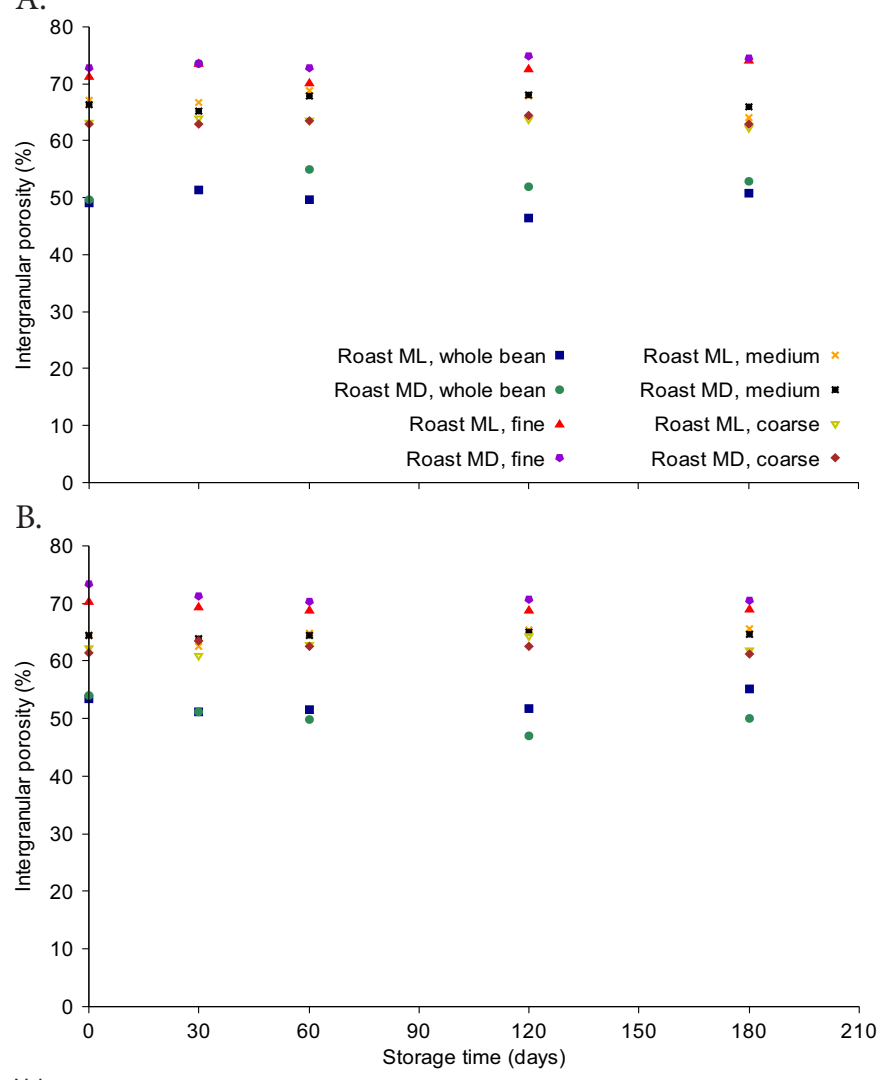

Values are averages

Figure 4. Intergranular porosity of roasted Arabica (A) and Robusta (B) coffees during storage at $10{ }^{\circ} \mathrm{C}$

\section{Conclusion}

True density, bulk density and intergranular porosity of coffee are proportional to the increased grind level, decreased roast level and decreased storage time.

\section{ACKnOWLedgements}

The authors wish to thank the National Council for Scientific and Technological Development - CNPq for the scholarships and financial support (CNPq $n^{\circ} 14 / 2012$, process number $483622 / 2012-5)$

\section{Literature Cited}

ABIC - Associação Brasileira da Indústria de Café. Norma de qualidade recomendável e boas práticas de fabricação de cafés torrados em grão e cafés torrados e moídos. Revisão 26. <http://www.abic.com. br/publique/media/Norma\%20de\%20qualidade.pdf >. 15 Out. 2013.

Baggenstoss, J.; Poisson, L.; Kaegi, R.; Perren, R.; Escher, F. Roasting and aroma formation: effect of initial moisture content and steam treatment. Journal of Agricultural and Food Chemistry, v.56, p.5847-5851, 2008. http://dx.doi.org/10.1021/jf8003288

Borges, M. L. A.; Mendonça, J. C. F.; Franca, A. S.; Oliveira, L. S.; Corrêa, P. C. Efeito da torração em parâmetros físicos de cafés de diferentes qualidades. Revista Brasileira de Armazenamento, v. Especial Café, p.6-13, 2004.

Fitzpatrick, J. J.; Barry, K.; Cerqueira, P. S. M.; Iqbal, T.; O’neill, J.; Roos, Y. H. Effect of composition and storage conditions on the flowability of dairy powders. Journal of Food Engineering, v.17, p.328-392, 2007. http://dx.doi.org/10.1016/j.idairyj.2006.04.010

Fitzpatrick, J. J.; Iqbal, T.; Delaney, C.; Twomey, T.; Keogh, M. K. Effect of powder properties and storage conditions on the flowability of milk powders with different fat contents. Journal of Food Engineering, v.64, p.435-444, 2004. http://dx.doi.org/10.1016/j. jfoodeng.2003.11.011

França, A. S.; Oliveira, L. S.; Borges, M. L. A.; Vitorino, M. D. Evolução da composição do extrato aquoso de café durante o processo de torrefação. Revista Brasileira de Armazenamento, v. Especial Café, p.37-47, 2001.

Geldart, D.; Abdullah, E. C.; Verlinden, A. Characterisation of dry powders. Powder Technology, v.190, p.70-74, 2009. http://dx.doi. org/10.1016/j.powtec.2008.04.089

Illy, A.; Vianni, R. Espresso coffee: The chemistry of quality. San Diego: Academic, 1995. 253p.

Iqbal, T.; Fitzpatrick, J. J. Effect of storage conditions on the wall friction characteristics of three food powders. Journal of Food Engineering, v.72, p.273-280, 2006. http://dx.doi.org/10.1016/j.jfoodeng.2004.12.007

Langroudi, M. K.; Sun, J.; Sundaresan, S.; Tardos, G. I. Transmission of stresses in static and sheared granular beds: The influence of particle size, shearing rate, layer thickness and sensor size. Powder Technology, v.203, p.23-32, 2010. http://dx.doi.org/10.1016/j.powtec.2010.03.028

Licciardi, R.; Pereira, R. G. F. A.; Mendonça, L. M. V. L.; Furtado, E. F. Avaliação físico-química de cafés torrados e moídos, de diferentes marcas comerciais, da Região Sul de Minas Gerais. Ciência e Tecnologia de Alimentos, v.25, p.425-429, 2005. http://dx.doi. org/10.1590/S0101-20612005000300006

Lopes Neto, J. P.; Nascimento, J. W. B. do; Silva, V. R. da. Efeito do tempo de armazenagem de rações avícolas no dimensionamento de silos. Engenharia Agrícola, v.29, p.518-527, 2009. http://dx.doi. org/10.1590/S0100-69162009000400002 
Melo, W. L. B. A importância da informação sobre do grau de torra do café e sua influência nas características organolépticas da bebida. São Carlos: Empresa Brasileira de Pesquisa Agropecuária, 2004. 4p. Comunicado Técnico, 58.

Mendonça, J. C. F.; Franca, A. S.; Oliveira, L. S. Physical characterization of non-defective and defective Arabica and Robusta coffees before and after roasting. Journal of Food Engineering, v.92, p.474-479, 2009. http://dx.doi.org/10.1016/j.jfoodeng.2008.12.023

Mohsenin, N. N. Physical properties of plant and animal materials. New York: Gordon and Breach Science Publishers, 1986. 918p.

Mwithiga, G.; Jindal, V. K. Physical changes during coffee roasting in rotary conduction-type heating units. Journal of Food Process Engineering, v.26, p.543-558, 2003. http://dx.doi. org/10.1111/j.1745-4530.2003.tb00655.x

Nóbrega, M. V.; Nascimento, J. W. B. do. Fluxo de ração avícola em silos prismáticos com tremonha excêntrica. Revista Brasileira de Engenharia Agrícola e Ambiental, v.9, p.413-419, 2005. http:// dx.doi.org/10.1590/S1415-43662005000300018

Oliveira, A. P. L. R.; Corrêa, P. C.; Reis, E. L.; Oliveira, G. H. H. Comparative study of the physical and chemical characteristics of coffee and sensorial analysis by principal components. Food Analytical Methods, v.8, p.1303-1314, 2015. http://dx.doi. org/10.1007/s12161-014-0007-4

Oliveira, G. H. H.; Corrêa, P. C.; Santos, F. L.; Vasconcelos, W. L.; Calil Júnior, C.; Baptestini, F. M.; Vargas-Elías, G. A. Caracterização física de café após torrefação e moagem. Semina: Ciências Agrárias, v.35, p.1813-1828, 2014. http://dx.doi.org/10.5433/1679$0359.2014 \mathrm{v} 35 \mathrm{n} 4 \mathrm{p} 1813$
Pegg, R. B.; Shahidi, F. Encapsulation, stabilization, and controlled release of food ingredients and bioactives. In: Rahman, M. S. (ed.). Handbook of food preservation. 2.ed. 2007. p.509-570.

Resende, O.; Corrêa, P. C.; Goneli, A. L. D.; Ribeiro, D. M. Propriedades físicas do feijão durante a secagem: determinação e modelagem. Ciência e Agrotecnologia, v.32, p.225-230, 2008. http://dx.doi. org/10.1590/S1413-70542008000100033

Schmidt, C. A. P.; Miglioranza, É.; Prudêncio, S. H. Interação da torra e moagem do café na preferência do consumidor do oeste paranaense. Ciência Rural, v.38, p.1111-1117, 2008. http://dx.doi. org/10.1590/S0103-84782008000400032

Schubert, H. Food particle technology. Part I: Properties of particles and particulate food systems. Journal of Food Engineering, v.6, p.1-32, 1987. http://dx.doi.org/10.1016/0260-8774(87)90019-7

Singh, P. C.; Singh, R. K.; Bhamidipati, S.; Singh, S. N.; Barone, P. Thermophysical properties of fresh and roasted coffee powders. Journal of Food Process Engineering, v.20, p.31-50, 1997. http:// dx.doi.org/10.1111/j.1745-4530.1997.tb00409.x

Teunou, E.; Fitzpatrick, J. J. Effect of storage time and consolidation on food powder flowability. Journal of Food Engineering, v.43, p.97-101, 2000. http://dx.doi.org/10.1016/S0260-8774(99)00137-5

Vargas-Elías, G. A. Avaliação das propriedades físicas e qualidade do café em diferentes condições de torrefação. Viçosa: UFV, 2011. 111p. Masters' Dissertation

Yan, H.; Barbosa-Canovas, G. V. Compression characteristics of agglomerated food powders: Effect of agglomerate size and water activity. Food Science and Technology International, v.3, p.351359, 1997. http://dx.doi.org/10.1177/108201329700300506 